LINGUA, Vol. 12, No. 1, Maret 2015

p ISSN: 1979 9411; e ISSN: 2442 238X; Web: lingua.pusatbahasa.or.id

Pusat Kajian Bahasa dan Budaya, Surakarta, Indonesia

Kasim, Usman. 2015. Implementation of Group Work in the Classroom.

Lingua, 12(1): 97 106.

\title{
IMPLEMENTATION OF GROUP WORK IN THE CLASSROOM
}

\author{
Usman Kasim \\ Syiah Kuala University, Banda Aceh \\ Email: usman_ksm@yahoo.com
}

\begin{abstract}
One of the techniques which is a breakthrough to traditional lock step language teaching is group work. The traditional lockstep language teaching focuses teaching language on the explicit explanation of grammatical aspects, asking students to read and translate line by line, memorizing difficult words, repeating words, phrases and sentences, and memorizing dialogues. This way, students tend to be passive and have lack of language practice in the classroom. In other words, language teaching focuses on presenting grammatical knowledge, not on the use of language. The traditional teaching now has been replaced by the various innovative and effective language teaching techniques since the emergence of communicative language teaching in 1970s. One of them is group work. Group work is learning together in a small group of four or five to work with language. Through group work, students can have more chance to practice the use of language in the classroom. Many research findings show that group work is superior to traditional language teaching in terms of learning achievement. Some of the activities which can be implemented through group work in the classroom are to be presented in this paper. They are game, role play, project, information gap, jigsaw, think pair and share, debate, enquiry technique, prioritizing (Expedition to Gunoeng Leuser), and fishbowl technique.
\end{abstract}

Key words: implementation, group work, classroom

People all over the world agree that English is becoming more and more important in this era of globalization. Many companies require their employees to have good command of English. Schools and Universities in the world require their potential students to have a good proficiency in English. Job seekers, students, professionals, businessmen, actors, actresses, teachers, drivers, and even housewives are learning English for their specific purposes. In addition, the need for English is indicated by the next coming new era of globalization in which Indonesia is a part of Asia Pacific Economic Community (APEC) and Asia Economic Community (Masyarakat Ekonomi Asia, abbreviated to MEA)which is to begin next year, 2015. Many teachers of English are frustrated on how to make their students successful in improving their English. Experts or researchers in English language teaching have made many efforts to develop this professionalism.

In line with the need and the development of English language teaching, its paradigm has then shifted from the traditional whole-class approach to a more communicative classroom. Teachers of English have always been trying hard to make their learning and teaching successful. In other words, they always seek effective techniques to make their students experiment with the target language. In traditional teaching, students are not given 
more chance to use the target language. This reason makes the English language teaching a failure. In English as a Foreign Language (EFL) classroom, the use of English language is highly required as there is hardly ever English language exposure available outside of schools. One of the solutions to make the students learning English as a foreign language maximize the use of English is by way of putting students into groups, called group work. Many researches on language teaching applying group works have shown that pair or group works are superior to the traditional classroom model. This article is intended to make an attempt to have a discussion on the traditional lockstep classroom; what group work is; advantages and disadvantages of using group work; group work activities comprising game, role play, project, information gap, jigsaw, think pair and share, debate, inquiry technique, prioritizing, and fishbowl technique.

\section{TRADITIONAL LOCKSTEP CLASSROOM}

Traditionally, the classroom was a place where students passively received explicit grammatical, vocabulary, and pronunciation explanation from their teachers. Teachers provided opportunities for the learners to practice the new items of a language. The teachers acted as the knower or authorizer who always dictated what the students had to do. The students sat quietly and nicely and received what the teachers transferred them. In other words, the students listened and wrote anything written on the board by their teacher. Teaching materials were given in textbooks and were graded based on the level of difficulty in grammatical aspects. Language learning achievement was measured by using discrete point test.

Long (1975) as quoted by Rogers (1981) states that "Lockstep classroom is a traditional form of classroom organization where a teacher makes an attempt to conduct a large heterogeneous group of (say) thirty secondary age EFL students through a language program as one unit ... obliging all students to cover the same ground at the same time, and at the same pace, via the same approach, method and technique, and using the same material." (p. iii). This model of teaching is the most commonly used model in teaching language especially in traditional classroom. With this model, the teacher typically begins a lesson by reviewing the previous material, then introduces and develops a new one, and then give students some homework. Richards (1996: 148) calls such a traditional class as 'teacher dominated', with little opportunity for active student participation.

In contrast to that of traditional approach, it is a trend towards an educational system in ESL/EFL which is flexible, dynamic, and capable of responding to changing educational needs. This trend is different from the traditional one, that is the trend which makes students actively involved in the process of learning and teaching where students have more chance to experiment with second/ foreign language, that is group work. In relation to this, the idea of 'social scaffolding' as proposed by Vygotsky as quoted by Quigly (2013) needs to be taken into account. The idea is that it a concept that most of our learning is undertaken in group situations, where we learn through dialogue and debate with others, not simply by listening to that voice in our head. With this idea, then, the role of the teacher is designing group works with appropriate tasks requiring the students to experiment with the target language. Students need to be given clear instructions on what to do and the criteria of expected outcome to be 
achieved. The teacher has an important role in guiding group works. The teacher should always look at the group whether it is on the right track or not, make the students focus, intervene them where it is necessary, and monitor their work to improve their learning achievements.

\section{WHAT GROUP WORK IS}

In contrast to traditional way of teaching and learning a second/foreign language where grammatical explanation, memorization and repetition were more dominant, the new trend emerged in reaction to the old one in the sense that: (1) learning is a natural part of growth and maturation, and therefore learning may take place even without teaching, if relevant to the felt needs or interests of the learners in language learning, (2) learning is individualized, and (3) teachers who do not dominate the classroom anymore, play variety of roles determined by the learners' needs in English learning. In line with this idea, group work was proposed as a way to attack the traditional lock step classroom.

What is then group work? According to Brown (2001:177), group work is a generic term covering a multiplicity of techniques in which two or more students are assigned a task that involves collaboration and self-initiated language. While Richards, at. al (1985:127) defines group work as a learning activity which involves a small group of learners working together. The group may work on a single task, or on different parts of a larger task. In addition, Harris and Sherblom (2008:4) define a group as a collection of at least three and ordinarily fewer than twenty individuals who are interdependent, influence one another over some period of time, share a common goal or purpose, assumed a specialized role, have a sense of mutual belonging, maintain norms and standards for group membership, and engage in interactive communication. From these definitions, it can be concluded that group work is a learning activity which involves learners working together in a small team or group to perform a task with the objective is to give more opportunities for the students to use or practice the language.

Group work, according to Johnson, et al (2008:29), can be classified into three general types: informal learning group, formal learning group, and study tams or cooperative based groups. The first types of group work, informal learning groups are clustering students in a single class session, for example asking the students to turn to their neighbor and spend two minutes for discussing a question posed to the students. The informal learning group can be used to focus students' attention on the materials to be learned, set a conducive mood in learning, help set expectations as to be covered in a class session, ensure that students cognitively process and rehearse the material being taught, summarize what was learned by the students and also before introducing the next session, and provide closure to an instructional session.

The second type, according to Johnson, et al (2008), is formal learning group. In this type of group work, the teams are formed to complete a specific task, such as performing a lab experiment, writing a report, carrying out a project, or prepare a paper for presentation. The latter type of group work is study teams or cooperative based group which are long-term groups with stable membership whose primary responsibility is to provide students with support, encouragement, and assistance in completing course requirements and assignments. 
In addition, study teams inform their members about lectures and assignment $\mathrm{s}$ when someone has missed a session.

Learning in the context of sharing, responding, and communicating with other students is a major teaching strategy in teaching context. Students who work individually often do not help progress significantly. Conversely, students who are working in groups often can solve complex problems with minimal assistance. The experience of working together not only helps students learn the materials, is also consistent with the real world.

\section{Advantages of Group Work}

Many research findings have shown that group work can give better learning achievements in English language teaching and learning. Research finding as Huda (1999:90) mentions the lockstep approach gives very little opportunity for the student to talk and to receive input for acquisition. In contrast of 30 students, for example, each student would only have a chance to speak for $1 / 30$ of period, in comparison with a group of 4 students in which each has an opportunity to speak for $1 / 4$ of the period. This is due to some merits of group work. Among the advantages of the group work, Brown (2001:177) mentions these advantages of group work. These are as the following:

\section{1). Group work generates interactive language}

In lockstep traditional classroom, teacher talk is more dominant. Teachers give students explicit explanation of grammar, drill the students, and lead whole class discussion. By doing so, the students get less opportunity to practice the language. They tend to be passive. Only a few students get chance to practice the language and consequently, the English lesson becomes very boring. Small group provides opportunities for student initiation, for face-to-face give and take, for practice in negotiation of meaning, for extended conversational exchanges, and for student adoption of roles that would otherwise be impossible. This is in line with what Long and Porter (1985) mentions that small group work generates more negotiation of meaning than teacher-fronted activities.

2). Group work offers an embracing affective climate

Brown (2001) further mentions that when the students are in groups, they feel more secured. They can not easily be criticized or insulted. Inhibited students become active and vocal in the process of learning and teaching. In small groups, they work together to achieve a certain goal. By working in groups, students' motivation and self-confidence increase.

\section{3). Group work promotes learner responsibility and autonomy.}

Compared to whole-class activity in which students tend to be passive and individual students relax so much and hide themselves in the class, group work makes students more responsible for action and progress. In small group, it is difficult for them to keep quiet and hide themselves. Therefore, all students get chance to experiment with the language being learned. 


\section{4). Group work is a step toward individualizing instruction}

Small group can help students with mixed abilities to accomplish different goals. It makes the teacher easy to recognize the individual difference in terms of age, cultural heritage, field of study, cognitive style, motivation, aptitude, and personality.

In addition to the above advantages, Brumfit (1994:87) mentions that group work provides a 'naturalistic environment'. This means that students in group work are free from anxiety to experiment with the target language. This is like when they are exposed to a certain linguistic environment in which they can pick up the language. Further, group work minimizes the occurrence of those unpleasant situations and maximizes the learning and satisfaction that result from working together. Jacob (1999) also touches some advantages of group work in cooperative learning.

\section{Disadvantages of group work}

In addition to the advantages mentioned above, Brown (2001:179) further mentions five weaknesses of the application of group work in the classroom. These are the problem of controlling students, the use of mother tongue during the work, the reinforcement of students' errors in the classroom, the difficulty to monitor all groups, and the last problem is related to the students' cognitive styles: some learners may prefer to work alone.

\section{GROUP WORK ACTIVITIES IN THE CLASSROOM}

\section{Game}

Students are put into several groups. Each group is given a set of procedure text. Each student in groups is given one card containing one of the steps of doing something. The students are then required to seek their partners based on the sequence of steps in procedure text. The students do this by reading loudly the words written on their cards. Then the students are asked to go to the front to present what they have done in the game. The teacher tests the students' comprehension about the procedure text and guides them in drawing conclusion on what they have learned from the material. After that, further exercise is given to strengthen their comprehension on procedure texts.

Using game in the classroom encourages students to use the target language spontaneously in real life situation. Game makes more fun in the classroom and therefore the students enjoy learning. When this occurs learning can takes place better.

\section{Role Play}

Tell the students that they are going to use role play to practice their speaking skill based on the competence to be achieved as mentioned in the teacher's lesson plan. Students are required to sit in groups of four or five depending on class size. In each group students are given roles such as the head of village, village secretary, village advisor, community leader, and a university student. In each group, they are given a task to solve a problem. The problem is that the village has been given an aspiration fund amounting to Rp. 200.000.000. In groups they should discuss by giving arguments where to spend the money on. The choices are as these: constructing a school building, constructing a bridge, constructing a mosque, and distributing it to poor people in that village. For this, prior to the task students should be 
exposed with some reading material related to the choices mentioned above. By doing so, the task can develop students' fluency in target language, generate students to use the language or interact with others in the classroom. In addition, it can increase students' motivation and make the teaching learning process more enjoyable.

\section{Project}

In this project the students are asked to conduct a survey on, for example, 'why do people smoke'. Students are put into groups of four or five. In groups, they are required to devise a questionnaire. The questions in the questionnaire should include respondents' smoking habit, types of cigarettes they smoke, the number of cigarettes they smoke a day, their reasons for smoking, kinds of disease they are suffering from, the amount of money they spend on smoking, their feeling about smoking in public spaces and on public transport, etc. Students are then told to interview people smoking at coffee shops, markets, or any other public places to collect some data using the questionnaire. The groups study the information they have collected and write a report. Each groups then presents the report of the survey to the class orally using power point for classroom discussion.

According to Harmer (1991:148), this project may require commitment and dedication from the students. It takes about two weeks of an intermediate class's time. The number of respondents could be about 20 or more. The same kind of thing could be done with other topics, such as 'why do people learn English', 'why do people like to eat fast food', 'why are some noodles are cheaper than the others?, etc.

\section{Information Gap}

Students are given instruction of what and how to do the task. Then, students are asked to be in pairs, student A and student B. Each student is given different texts. Student A is given a reading text about a biography of a famous figure, for example William Shakespeare (English dramatist and poet) and student B is given a reading text about Jeffrey Archer (writer of novels). Student A has some questions about Jeffrey Archer regarding his date of birth, educational background, time of his marriage, time of his involvement in parliament, about his novels, when he returned to politics, his job, and the name of party he belong to. Student B is also given some questions about William Shakepeare. The questions ask about his date of birth, his nationality, his job, his date of marriage, name of his wife, what he did in 1594, when he bought Globe Theatre, what happened to him in 1613, number of plays he wrote, sort of plays he wrote, and time of his death. In pair, they exchange the information by asking and answering the questions to each other. The answers should be written on the spaces provided below each question. After they have finished the task, the teacher and the students check whether the answers written are correct or not. By doing so, the students have more practice of using the target language in a conducive learning atmosphere.

\section{Jigsaw}

Jigsaw activity helps students create their own learning. Teachers put students in group of four or five. Each member of the groups is given a number, for example, student 1, 
2, 3, 4, and 5 (if one group consists of five students) or student T, E, A, and M (TEAM) and each of them is assigned a different text or information. Then, group members join with members of other groups assigned the same text or information, and research and/or share ideas about the text or information. Then, students return to their original groups to teach other members of the groups who have different texts or information. Group members must work together as a team to accomplish a common goal and each person is dependent on each other. By doing so, it facilitates interaction among all students in the class. Clarke in Sharan (1994:35) states that each group member becomes specialized in subject matter and thereby possess critical information to contribute to classmates.

\section{Think Pair and Share}

Students are given some instructions about what to do with this activity. The teacher distributes parts of the text to the students. In every meeting there is a text that can be discussed. A text is divided into two parts. The students accept different part of the text. Then, the teacher asks the students to do the thinking step individually and try to understand it. The teacher monitors and controls the process of Thinking that is done individually by the students. After that, the students do the pairing step in pairs. They move closer to their pairs who have the same text, then think and share the text. The teacher monitors and controls the Pairing process that is done in pairs. The teacher may help the students if needed, especially with vocabulary problems. Next, the students do sharing step in pair, but with different pair. They should move to the other pairs who have different text in order to share the information from their texts. In addition, they should also pay attention to their new pairs' explanation. They also may ask other students, if the explanation is not clear enough, especially the ideas of the complete/full text. They also should find the answers of some exercises during the explanation. It means the students need to discuss what they have read before. The teacher monitors and controls the process of Sharing that is done in pair and in group and give necessary helps, especially on the comprehension. Then, they must back to their own pairs and discuss what they have got from Sharing step. The representative of each pair reports the result of discussion, other students may give comments/opinion. The teacher should give more explanation about the characteristics of the text, and the ideas as well to empower the material comprehension.

\section{Debate}

Students are given a controversial proposition related to current issues, for example the increase in oil price (BBM), early marriage, Direct or indirect general election, final national examination (UN), banning smoking in public areas, etc. Students are divided into two groups. One group must stand as 'for' and the other as 'against' on the chosen topic they want to discuss. Each group must provide arguments. A student should be appointed as a moderator chairing the discussion and one student acts a secretary writing necessary points from the discussion. Conclusion should be drawn based on the arguments given by each group. Prior to the activity, the students should be exposed to some reading materials related to the issues, so that they can have some ideas and vocabulary for the discussion. During the 
LINGUA, Vol. 12, No. 1, Maret 2015

p ISSN: 1979 9411; e ISSN: 2442 238X; Web: lingua.pusatbahasa.or.id

Pusat Kajian Bahasa dan Budaya, Surakarta, Indonesia

Kasim, Usman. 2015. Implementation of Group Work in the Classroom.

Lingua, 12(1): 97 106.

activity, the teacher may go around controlling, monitoring, offering help, and making sure each student gives contribution to the discussion.

\section{Inquiry technique}

This technique can be used to teach writing, for example writing descriptive text. The activities that can be done in groups in the classroom are as these. 1 . The teacher writes the topic on white the board (names of an animal. 2. The teacher asks students to mention the names of animals found around their areas. 3. Students raise their hand to mention the animals. 4. The teacher writes down the animals mentioned by the students on whiteboard. 5 . Students are divided into groups of four or five (depending on the size of the class. 6. Each group gets an envelope containing animal pictures from his teacher. 7. Students get instruction from their teacher on how to do the task in groups, what to do, time allocation, etc. 8. The teacher walks around to each group to make sure that every student does the activities. 9. Each group presents the result of discussion in front of the class (for example, it is about an animal. It has sharp eyes, long tail, etc.). 10. Other students in groups try to ask (enquire)to get the name of the animal (for example, Does it live in the house, Does it eat meat? Does it et fish?, etc.). 11. The teacher asks each group to show the answer. 12. Again students in each group do other activities (Write down about fifty words describing about the picture they have. 13. Each group reads the paragraph in front of the class. 14. Each group sticks their pictures and 50 words below the picture on the wall. 15. The teacher and students make conclusion about the lesson.

\section{Prioritizing (Expedition to Gunoeng Leuser)}

Students are put into groups of four or five depending on the number of students in one class. Each member of a group is assigned as a leader, a secretary, a spoke person, and a member. The teacher tells the class that they are going to conduct an expedition to Gunoeng Leuser or any other place or mountain in Aceh or other parts of Indonesia. Before they leave for the location, they have to prepare some important items which enable them to go to the location. Tell them that they cannot take everything they have to the location, since there is no transportation surrounding the mountain. So, in groups, students discuss and list the items from the most important items to the least important ones. The teacher should limit the items to 25 only and the time given should be 10 or 15 minutes. During the discussion, the teacher goes around to monitor and control the discussion while offering helps to the students. Make sure that all students contribute in the discussion and encourage them to use the target language. After the discussion, each group represented by a spoke person reports the result of the discussion, while the other groups have to listen to the report and put a tick on the items which are the same. The other groups just report the items which are not mentioned by the group who has reported. When this is over, then the students are asked again to sit in groups to prioritize the items to only 15 items and each item proposed should be given reasons.

\section{Fishbowl technique}

This technique can be used for many things: to model for discussions or other classroom instructional method, and also to help students think critically about a topic. This is 
how to do it in the classroom. 1. The teacher identifies a small group of students (4-5 students). The teacher provides the students with a topic to discuss. This topic can come from the readings for the class, from class lecture, , from students' experiences, etc. 2.If there is time, students in this group can research an issue, topic, or problem. The students in this group sit in the center of the room. These students are in the "fishbowl". The remaining students sit in a circle around them. 4. The students in the center discuss their topic. 5. While the students in the center are discussing, the audience (the other students) pay attention to the conversation. They can write down things like: what works well in a good discussion, what does not work well for a good discussion, interesting ideas that come up, questions, etc. 6. At some point, the teacher stops the students in the "fishbowl". Then, the teacher begins a discussion with the whole class. The discussion should be based on what occurs in the "fishbowl" discussion (Unsyiah, University of Kentucky, and USAIDS, 2010).

\section{CONCLUSION}

Based on the discussion in the previous parts, this article can come to a conclusion. One of the efforts that should be made by the teachers of English to maximize communication and interaction in the classrooms at schools in Indonesia where English is considered as a foreign language is by forming group work. Group work is a technique by which students can work or learn together to do the tasks in small teams consisting of four or five students of different abilities. There are some reasons for group work to be superior: generating interactive language, offering embracing affective climate, promoting learner responsibility, and autonomy, and a step toward individualizing instruction. On the other hand, group work may also have problems such as no longer in control of the class, the use of students' native language, the reinforcement of students' errors, and the difficulty to monitor all groups, but this can be overcome by teachers. Group work can be implemented in the classroom through a number of tasks or activities with which students can practice the target language. These activities are game, role play, project, information gap, jig saw, think pair and share, debate, inquiry technique, prioritizing, and fishbowl technique.

\section{REFERENCES}

Brown, H. Douglas. 2001. Teaching by Principles. An Interactive Approach to Language Pedagogy. New York: Longman.

Brumfit, C. 1984. Methodology Communicative in Language Teaching: The Role of Fluency and Accuracy. Cambridge: Cambride University Press.

Clarke, Judi. 1994. Shlomo Sharan (Ed.). Cooperative Learning Methods. London: Praeger.

Harmer, Jeremy. 1991. The Practice of English Language Teaching. New Edition. New York: Longman Publishing.

Huda, Nuril. 1999. Language Learning and Teaching: Issues and Trends. Malang: Universitas Negeri Malang.

Jacob, Evelyn. 1999. Cooperative Learning in Context: An Educational Innovation in Everyday Classroom. New York: State University of New York Press. 
Johnson, D. \& Johnson, R. 1999. Cooperative Learning. Free Article. Retrieved January 23, 2010 from http:www.accessmylibrary.com/article-1G1-149837166/Improvingreading-comprehension-middle.html.http:/www.lang.edu/teachervision.com

Quigly, Alex. 2013. Top Ten Group Work Strategies. www.hunting English.com/2013/12. Accessed December 11, 2014.

Richards, Platt, \& Weber. 1985. Longman Dictionary of Applied Linguistics. Essex: Longman Group Limited.

Richards, Jack C. and Charles Lockhart. 1996. Reflective Teaching in Second LanguagebClassrooms. Cambridge: Cambridge University Press.

Rogers, John. 1981. Group Activities for Language Learning. Singapore: SEAMEO-RELC.

Unsyiah, University of Kentucky, and USAIDS. 2010. Short Course. Planning Pre-Service Teacher Preparation Programs with a Focus on PAKEM. $13-15^{\mathrm{TH}}$ January, 2010. LRC Bungong Keumang, SMA Lab School, Syiah Kuala University. 